examens car il donnent des indices améliorés de l'activité enzymolitique et réduisent la durée de la plantation.

\section{Pièces utilisées}

1. Karmakar, M. Current trends in research and application of microbial cellulases [Text] / M. Karmakar, R. Ray, J. Res. // Microbiol. - 2011. - Vol. 4, Issue 6. - P. 4153. doi: $10.3923 / \mathrm{jm} .2011 .41 .53$

2. Sheveluha, E. A. Agricultural biotechnology [Text] / E. A. Sheveluha - Moscow: Higher School, 2004. - 265 p.

3. Cheshkova, A. V. Using bioprocess at finish mixture of fabrics and claps chemical fibers [Text] / A. V. Cheshkova // Chemical fiber. - 2007. - Vol. 4. - P. 52-54.

4. Daison, B. Biocatalytic conversion of lignocellulose to platform chemicals [Text] / B. Daison, K. Konnely // Biotechnology. - 2012. - Vol. 43. - P. 13-21.

5. Kumar, D. Stochastic molecular model of enzymatic hydrolysis of cellulose for ethanol production [Text] / D. Kumar, G. S. Murthy // Biotechnology for Biofuels. 2013. - Vol. 6, Issue 63. - P. 20.
6. Beguin, P. The biological degradation of cellulose [Text] / P. Beguin, P. Aubert // FEMS Microbiol. Rev. - 2005. Vol. 14, Issue 3. - P. 5-58.

\section{References}

1. Karmakar, M., Ray, R., Res, J. (2011). Current trends in research and application of microbial cellulases. Microbiol., 4 (6), 41-53. doi: 10.3923/jm.2011.41.53

2. Sheveluha, E. A. (2004). Agricultural biotechnology. Higher School, 265.

3. Cheshkova, A. V. (2007). Using bioprocess at finish mixture of fabrics and claps chemical fibers. Chemical fiber, 4 , $52-54$.

4. Daison, B. J., Konnely, K. (2012). Biocatalytic conversion of lignocellulose to platform chemicals. Biotechnology, 43, 13-21.

5. Kumar, D., Murthy, G. S. (2013). Stochastic molecular model of enzymatic hydrolysis of cellulose for ethanol production. Biotechnology for Biofuels, 6 (63), 20.

6. Beguin, P., Aubert, P. (2005). The biological degradation of cellulose. FEMS Microbiol. Rev., 14 (3), 5-58.

Рекомендовано до публікаиії д-р біол. наук Пирог Т. П. Дата надходження рукопису 24.10.2014

Nekleva Yulia, Étudiante, ingénieur de la 1e catégorie, La chaire de biotechnologie et microbiologie, Université Nationale de Technologie Alimentaire, Institut de Microbiologie et Virologie Zabolotny de l'Académie nationale des Sciences, 68, rue Volodymyrska, 01601 Kyiv-33, Ukraine, 154, rue Akademika Zabolotnogo, Kyiv, région de Kyiv, 03680

E-mail: pasikyulia@gmail.com

Krasinko Viktoria, Docteur ès sciences techniques, maître de conférences, La chaire de biotechnologie et microbiologie, Université Nationale de Technologie Alimentaire, 68, rue Volodymyrska, 01601 Kyiv-33, Ukraine

E-mail: vkrasinko@ukr.net

Syrchin Serhii, Docteur ès sciences biologiques, chercheur en chef, Département de Physiologie et de Systématique des Micromycètes, Institut de Microbiologie et Virologie Zabolotny de l'Académie nationale des Sciences, 154, rue Akademika Zabolotnogo, Kyiv, région de Kyiv, 03680

E-mail: syrchin@ukr.net

УДК 636.4:577.115:612.176

DOI: $10.15587 / 2313-8416.2014 .29418$

\title{
ВМІСТ ФОСФОЛІПІДІВ У КРОВІ СВИНЕЙ ЗА УМОВ СТРЕСУ
}

\author{
(ㄱ) С. С. Грабовський, О. С. Грабовська, А. 3. Пилипець
}

Стаття присвячена дослідженню вмісту окремих фракиій фосфоліпідів у плазмі крові свиней перед забоєм. Як біологічно активні речовини у передзабійний період (за 5 днів до забою) застосовували екстракт селезінки, отриманий з використанням ультразвуку (І дослідна група). Встановлено вплив біологічно активних речовин з екстракту селезінки за умов передзабійного стресу на вміст окремих фракиій фосфоліпідів у плазмі крові свиней.

Ключові слова: передзабійний стрес, екстракт селезінки, свині, плазма крові, фосфоліпіди.

The article is devoted to the researching of some phospholipids content in pigs' blood plasma before slaughter. Obtained with the application of ultrasound spleen extract as the biologically active substances has been additionally entered to the pigs feed (I experimental group) at 5 days before slaughter. The results about influence biologically active compounds from the spleen extract at for pre-slaughter stress on separate phospholipids classes content in pigs' blood plasma were obtained.

Keywords: pre-slaughter stress, spleen extract, pigs, blood plasma, phospholipids.

\section{1. Вступ}

На стан організму сільськогосподарських тварин під впливом передзабійного стресу, а згодом і на людину, яка споживає продукцію від цих тварин, зовсім не звертається увага. У літературі обмаль повідомлень про передзабійний стрес у тварин. Проте, нашими попередніми дослідженнями [1] було показано позитивний вплив антистресорів та імуномодуляторів природного походження (екстракт селезінки) на окремі класи ліпідів та фракції 
фосфоліпідів у плазмі крові курчат-бройлерів при передзабійному стресі.

\section{2. Постановка проблеми}

Метою досліджень було вивчення змін вмісту окремих фракцій фосфоліпідів у плазмі крові свиней перед забоєм i їх корекція біологічно активними речовинами природного походження.

\section{3. Літературний огляд}

Дослідженням впливу короткострокового психологічного стресу на концентрацію ліпідів у крові людей присвячено немало робіт $[2,3]$, а про передзабійний стрес у тварин у літературі $є$ дуже мало відомостей. Стресовий стан у сільськогосподарських тварин і свиней, зокрема, викликає не тільки економічні втрати, але й погіршення якості продукції [4-6]. Ліпіди та фосфоліпіди, які $\epsilon$ неполярним середовищем для жиророзчинних субстратів і кофакторів ензимів, забезпечують відповідну орієнтацію білків у мембранах клітин, зумовлюють їх конформаційні зміни і є регуляторами та модуляторами ензимної активності у клітині [7]. Співвідношення окремих підкласів фосфоліпідів, ступінь насиченості жирних кислот, які є у складі фосфоліпідів, визначають плинність ліпідного бішару мембрани, впливають на впорядкованість ліпідних молекул, а також характер ліпід- і білокліпідних взаємодій [8]. Збільшення мікров'язкості ліпідів плазматичних мембран призводить до зниження активності мембранзв'язаних ензимів та порушення важливих для клітини процесів [9]. Передзабійний стрес усунути повністю неможливо, тому виникає необхідність підвищення імунного статусу тварини та використання антистресорів природного походження.

\section{4. Вміст підкласів фосфоліпідів у крові кнурців за умов стресу}

Дослід провели на 15 кнурцях породи ПетренДюрок, яких утримували у клітках на сухому кормі ТзОВ «Лемберг-Агро» села Ліщини Жидачівського району Львівської області. Для дослідження було сформовано три групи тварин 6-місячного віку (по 5 тварин у кожній). Як біологічно активні речовини у передзабійний період (за п'ять діб до забою) використовували екстракт селезінки, одержаний із використанням ультразвуку (I дослідна група).
Екстракти наносили на сухий корм аерозольним методом $\left(70^{\circ}\right.$ спиртовий розчин екстракту селезінки об'ємом 1,4 мл на тварину). Тваринам II дослідної групи таким же чином давали до корму $70^{\circ}$ спиртовий розчин в аналогічному об'ємі. Кнурці контрольної групи отримували лише сухий корм господарства. При експерименті усі біоетичні норми згідно з Свропейською конвенцією «Про захист хребетних тварин, які використовуються для експериментальних і наукових цілей» (Страсбург, 1986 р.) і «Загальних етичних принципів експериментів на тваринах», ухвалених Першим Національним конгресом з біоетики (Київ, 2001) та дотриманням принципів гуманності, викладеними у директиві Європейської Спільноти [10] були збережені.

Вміст фосфоліпідів визначали за методом Фолча [11], розділення на фракції - методом тонкошарової хроматографії [12]. Математичну обробку результатів опрацьовували статистично за допомогою пакету програм Statistica6.0 и Microsoft Excel for Windows XP. Вірогідність різниць оцінювали за t-критерієм Стьюдента.

Аналізуючи отримані дані вмісту окремих фракцій фосфоліпідів (табл. 1,2) у плазмі крові кнурців до та після транспортування при додаванні до раціону біологічно активних речовин екстракту селезінки виявлено, що у тварин усіх досліджуваних груп переважають фосфатидна кислота, кардіоліпін. Найменшу кількість встановлено - фосфатидилінозитолу до транспортування і фосфатидилхоліну після транспортування та перед забоєм тварин.

До транспортування рівень кардіоліпіну у плазмі крові кнурців обох дослідних груп знизився майже у два рази порівняно 3 контролем $(\mathrm{P} \leq 0,01)$ (табл. 1$)$, тоді як після транспортування та перед забоєм - підвищився майже у чотири рази порівняно 3 контролем $(\mathrm{P} \leq 0,01)$ (табл. 2), при чому лише у кнурців I дослідної групи. Вміст лізолецитину був вищий майже втричі лише у тварин II дослідної групи $(\mathrm{P} \leq 0,01)$ до транспортування.

Вміст фосфатидної кислоти після транспортування та перед забоєм збільшився у плазмі крові кнурців I дослідної групи $(\mathrm{P} \leq 0,01)$ у порівнянні 3 контролем. Фосфатидна кислота продукт дії фосфоліпаз С та Д i виступає у клітинному матриксі як вторинний месенджер.

Таблиця 1

Вміст підкласів фосфоліпідів у плазмі крові свиней до транспортування, \% $(\mathrm{M} \pm \mathrm{m}, \mathrm{n}=5)$

\begin{tabular}{|c|c|c|c|c|c|c|c|}
\hline Лізолецитин & Сфінгоміелің & $\begin{array}{c}\text { Фосфатидил } \\
\text { серин }\end{array}$ & $\begin{array}{c}\text { Фосфатидил } \\
\text { холін }\end{array}$ & $\begin{array}{c}\text { Фосфатидил } \\
\text { інозитол }\end{array}$ & $\begin{array}{c}\text { Фосфатидил } \\
\text { етаноламін }\end{array}$ & $\begin{array}{c}\text { Кардіоліпін } \\
\text { Дослід I } \\
\text { кислота }\end{array}$ \\
\hline $9,19 \pm 3,44^{* *}$ & $8,51 \pm 5,92$ & $12,50 \pm 4,30$ & $6,78 \pm 3,42$ & $6,96 \pm 4,25$ & $8,50 \pm 2,45$ & $13,01 \pm 3,88^{* * *}$ & $34,45 \pm 9,98$ \\
\hline $8,82 \pm 5,09$ & $9,46 \pm 7,15$ & $10,38 \pm 5,93$ & $10,81 \pm 7,12$ & $7,11 \pm 1,70$ & $10,32 \pm 8,83$ & $16,42 \pm 4,02 * * * 2$ & $21,72 \pm 13,64$ \\
\hline \multicolumn{7}{|c|}{ Контроль } \\
\hline $3,59 \pm 1,58$ & $5,89 \pm 3,01$ & $11,31 \pm 10,17$ & $3,61 \pm 3,42$ & $5,80 \pm 1,95$ & $14,80 \pm 9,26$ & $27,39 \pm 9,10$ & $27,61 \pm 7,00$ \\
\hline
\end{tabular}

Примітка: у цій та наступній таблиці вірогідні різниці між дослідом і контролем * - $\mathrm{P} \leq 0,05$; ** — $\mathrm{P} \leq 0,01$ 
Вміст підкласів фосфоліпідів у плазмі крові свиней після транспортування та перед забоєм, \% $(\mathrm{M} \pm \mathrm{m}, \mathrm{n}=5)$

\begin{tabular}{|c|c|c|c|c|c|c|c|}
\hline Лізолецитин & Сфінгоміелін & $\begin{array}{c}\text { Фосфати- } \\
\text { дил серин }\end{array}$ & $\begin{array}{c}\text { Фосфатидил } \\
\text { холін }\end{array}$ & $\begin{array}{c}\text { Фосфатидил } \\
\text { інозитол }\end{array}$ & $\begin{array}{c}\text { Фосфатидил } \\
\text { етаноламін }\end{array}$ & $\begin{array}{c}\text { Кардіоліпін } \\
\text { Дослід I }\end{array}$ & $\begin{array}{c}\text { Фосфатидна } \\
\text { кислота }\end{array}$ \\
\hline \multicolumn{7}{|c|}{ Дослід II } \\
\hline $4,63 \pm 4,14$ & $7,60 \pm 6,07$ & $3,60 \pm 2,78$ & $4,12 \pm 2,06$ & $13,64 \pm 12,90$ & $14,44 \pm 6,72$ & $28,83 \pm 17,03 * *$ & $23,49 \pm 3,21 * *$ \\
\hline $11,44 \pm 6,36$ & $12,81 \pm 6,43$ & $9,02 \pm 3,86$ & $6,56 \pm 5,26$ & $19,21 \pm 9,98$ & $14,30 \pm 8,27$ & $12,54 \pm 7,85$ & $16,03 \pm 5,30$ \\
\hline $8,52 \pm 3,18$ & $13,58 \pm 2,53$ & $\begin{array}{c}13,01 \pm 9,6 \\
5\end{array}$ & $3,81 \pm 3,55$ & $17,19 \pm 13,61$ & $15,06 \pm 12,58$ & $7,69 \pm 1,74$ & $16,14 \pm 4,45$ \\
\hline
\end{tabular}

Таким чином, виявлено вплив антистресорів та імуномодуляторів, одержаних з екстракту селезінки із застосуванням ультразвуку, при передзабійному стресі на вміст окремих підкласів фосфоліпідів у плазмі крові кнурців.

\section{6. Висновки}

На завершальній стадії відгодівлі свиней слід враховувати передзабійний стрес на організм та застосовувати біологічно активні речовини природного походження, які сприятимуть зменшенню негативного впливу такого стресу на якість продукції від цих тварин.

\section{Література}

1. Грабовський, С. С. Вміст окремих класів ліпідів у крові курчат-бройлерів при передзабійному стресі [Текст]/ С. С. Грабовський // Біологія тварин. - 2013. - Т. 15, № 4. C. 24-31.

2. Faghihi, T. A Randomized, Placebo-Controlled Trial of Selenium Supplementation in Patients With Type 2 Diabetes: Effects on Glucose Homeostasis, Oxidative Stress, and Lipid Profile [Text] / T. Faghihi, M. Radfar, M.Barmal et al. // American Journal of Therapeutics. - 2014. - Apr 29.

3. Gitto, E. Oxidative stress in the newborn in the pre- and postnatal period and the clinical utility of melatonin [Text] / E. Gitto, S. Pellegrino, P. Gitto et al. // Journal of Pineal Research. - 2009. - Vol. 46, Issue 2. - P. 128-139. doi: 10.1111/j.1600-079x.2008.00649.x

4. Dokmanović, M. The effects of lairage time and handling procedure prior to slaughter on stress and meat quality parameters in pigs [Text] / M. Dokmanović, A. Velarde, V. Tomović et al. // Meat science. - 2014. - Vol. 98, Issue 2. P. 220-226. doi: 10.1016/j.meatsci.2014.06.003

5. Kim, Y. H. B. Influence of high pre-rigor temperature and fast $\mathrm{pH}$ fall on muscle proteins and meat quality: a review [Text] / Y. H. B. Kim, R. D. Warner, K. Rosenvold // Animal Production Science. - 2014. - Vol. 54, Issue 4. - P. 375-395. doi: $10.1071 /$ an 13329

6. Rocha, L. M. Effects of ractopamine administration and castration method on the response to preslaughter stress and carcass and meat quality in pigs of two Pietrain genotypes [Text] / L. M. Rocha, A. M. Bridi, A. Foury et al. / Journal of animal science. - 2013. - Vol. 91, Issue 8. - P. 3965-3977. doi: $10.2527 /$ jas.2012-6058

7. Nakamura, M. T. Structure, function and dietary regulation of delta- 6 , delta- 5 and delta-9 desaturases [Text] / M. T. Nakamura, T. Y. Nara // Annual Review of Nutrition. 2004. - Vol. 24. - P. 345-376.

8. Decsi, T. Polyunsaturated fatty acids in plasma lipids of obese children with and without metabolic cardiovascular syndrome [Text] / T. Decsi, G. Csabi, Torok K. et all. // Lipids. - 2000. - Vol. 35, Issue 11. - P. 1179-1184. doi: $10.1007 / \mathrm{s} 11745-000-0634-7$
9. Nkondjock, A. Specific fatty acids and human colorectal cancer: an overview [Text] / A. Nkondjock, B. Shatenstein, P. Maisonneuve // Ghadirian Cancer Detect Prev. - 2003. - Vol. 27, Issue 1. - P. 55-62. doi: 10.1016/s0361-090x(02)00179-4

10. Official Journal of the European Union L276/33 [Text] / Directive 2010/63/EU of the European parliament and of the council of 22 September 2010 on the protection of animals used for scientific purposes. 86/609/EC. 20.10.2010.

11. Folch, J. Asimple method for the isolation and purification of total lipids fromanimal tissues [Text] / J. Folch, M. Lees, G. Stauley // J. Biol. Chem. - 1957. - Vol. 226. P. 497.

12. Влізло, В. В. Лабораторні методи досліджень у біології, тваринництві та ветеринарній медицині [Текст]: довідник / В. В. Влізло, Р. С. Федорук, І. Б. Ратич та ін.; за ред. В. В. Влізла. - Львів: Сполом, 2012. - 764 с.

\section{References}

1. Grabovskyi, S. S. (2013). Some lipid classes content in broiler chickens blood at pre-slaughter stress. The Animal Biology, 15 (4), 24-31. [In Ukrainian].

2. Faghihi, T., Radfar, M., Barmal, M., Amini, P., Qorbani, M., Abdollahi, M., Larijani, B. (2013) A Randomized, PlaceboControlled Trial of Selenium Supplementation in Patients With Type 2 Diabetes: Effects on Glucose Homeostasis, Oxidative Stress, and Lipid Profile. American Journal of Therapeutics. Apr 29. [Epub ahead of print].

3. Gitto, E., Pellegrino, S., Gitto, P. et al. (2009). Oxidative stress in the newborn in the pre- and postnatal period and the clinical utility of melatonin. Journal of Pineal Research, 46 (2), 128-139. doi: 10.1111/j.1600-079x.2008.00649.x

4. Dokmanović, M., Velarde, A., Tomović, V., Glamočlija, N., Marković, R., Janjić, J., Baltić, M. Ž. (2014). The effects of lairage time and handling procedure prior to slaughter on stress and meat quality parameters in pigs. Meat science, 98 (2), 220 226. doi: 10.1016/j.meatsci.2014.06.003

5. Kim, Y. H. B., Warner, R. D., Rosenvold, K. (2014). Influence of high pre-rigor temperature and fast $\mathrm{pH}$ fall on muscle proteins and meat quality: a review. Animal Production Science, 54 (4), 375-395. doi: 10.1071/an13329

6. Rocha, L. M., Bridi, A. M., Foury, A., Mormede, P., Weschenfelder, A. V., Devillers, N., Faucitano, L. (2013). Effects of ractopamine administration and castration method on the response to preslaughter stress and carcass and meat quality in pigs of two Pietrain genotypes. Journal of animal science, 91 (8), 3965-3977. doi: 10.2527/jas.2012-6058

7. Nakamura, M. T., Nara, T. Y. (2004). Structure, function and dietary regulation of delta- 6 , delta-5 and delta- 9 desaturases. Annual Review of Nutrition, 24, 345-376.

8. Decsi, T., Csabi, G., Torok, K. et al. (2000). Polyunsaturated fatty acids in plasma lipids of obese children with and without metabolic cardiovascular syndrome. Lipids, 35 (11), 1179-1184. doi: 10.1007/s11745-000-0634-7 
9. Nkondjock, A., Shatenstein, B., Maisonneuve, P. (2003). Specific fatty acids and human colorectal cancer: an overview. Ghadirian Cancer Detect Prev, 27 (1), 55-62. doi: 10.1016/s0361-090x(02)00179-4

10. Official Journal of the European Union L276/33 (2010). Directive 2010/63/EU OF the european parliament and of the council of 22 September 2010 on the protection of animals used for scientific purposes. 86/609/EC. 20.10.2010.
11. Folch, J., Lees, M., Stauley, G. (1957). Asimple method for the isolation and purification of total lipids fromanimal tissues. J. Biol. Chem., 226, 497.

12. Vlizlo, V. V., Fedoruk, R. S., Ratych, I. B. et al. (2012). Laboratory methods of investigation in biology, stockbreeding and veterinary. Reference book ; Edited by V. V. Vlizlo. Lviv : SPOLOM, 764. [in Ukrainian].

Рекомендовано до публікаиії д-р біол. наук, професор Малик О. Г. Дата надходження рукопису 31.10.2014

Грабовський Степан Стефанович, кандидат біологічних наук, кафедра біологічної та загальної хімії, Львівський національний університет ветеринарної медицини та біотехнологій імені С. З. Гжицького, вул. Пекарська, 50, Львів, 79010, Україна,

E-mail: grbss@ukr.net

Грабовська Олександра Степанівна, кандидат біологічних наук, Лабораторія інтелектуальної власності та маркетингу інновацій, Інститут біології тварин НААН, вул. В. Стуса, 38, м. Львів, 79034, Україна E-mail: alice_grb@ukr.net

Пилипець Андрій Зіновійович, кандидат сільськогосподарських наук, Лабораторія інтелектуальної власності та маркетингу інновацій, Інститут біології тварин НААН, вул. В. Стуса, 38, м. Львів, 79034, Україна

E-mail: alice_grb@ukr.net

УДК: 167.33:616.36-004+599.323.41

DOI: 10.15587/2313-8416.2014.29151

\title{
МОДЕЛЮВАННЯ ТОКСИЧНОГО ПОШКОДЖЕННЯ ПЕЧІНКИ НА ЛІНІЇ МИШЕЙ ICR
}

\author{
(C) М. В. Драгулян, Т. П. Гулько, В. А. Кордюм, Р. В. Бубнов, О. Г. Дерябіна
}

\begin{abstract}
Цироз печінки є важким ускладненням хвороби печінки. Використання тварин із синтетично індукованим 30 \% масляним розчином CCl4 ураженням печінки дає можливість більш глибше та доскональніше вивчати морфологічні та функиіональні зміни иього органу. Використовуючи біохімічні, иитологічні, гістологічні, рентгенологічні та морфометричні методи нами було встановлено, що в печінці експериментальних самиів-мишей лінії ICR з модельним пошкодження печінки спостерігаються глибокі зміни з подальшим розвитком незворотних новоутворень.

Ключеві слова: миші лінії ICR, печінка, некроз, фіброз, цироз, новоутворення,CCl4, АЛТ, АCT, УЗД.
\end{abstract}

Cirrhosis is severe complications of liver disease. Using animals with synthetically induced $30 \%$ oil solution of CCl4-induced liver injury enables deeper study morphological and functional changes of the body. Using biochemical, cytological, histological, radiological and morphometric methods, we have found that profound changes with subsequent development of irreversible tumors are observed in the liver of experimental male-ICR mice with a model of liver damage.

Keywords: ICR mice line, liver, necrosis, fibrosis, cirrhosis, cancer, CCl4, ALT, AST, ultrasonic diagnostics.

\section{1. Вступ}

Цироз печінки - хронічне захворювання печінки, для якої характерне значне зменшення маси функціонуючих гепатоцитів і яке супроводжується порушенням іiі функціональної діяльності. Цьому захворюванню передує запалення печінки, фіброз печінки [1]. Найчастіше ця хвороба вражає людей 3 послабленим імунітетом, які хворіли на різні інфекційні захворювання (наприклад гепатит). Досі залишається невивченою зона ризику набутих хвороб печінки (гепатит, фіброз, цироз) у людей, які мають схильність до раку молочної залози (є фактом, що рак викливається вірусом). Залишається невивченим питання, щодо ймовірності не тільки набути хвороби печінки, а й можливості розвитку раку печінки - гепатоцерулярної карциноми [2]. Захворювання печінки зазвичай має тривалий перебіг, без клінічних симтомів. Важлива причина хвороби - тривале ведення токсинів, що ослаблює мембрану гепотоцитів. Послаблена мембрана чутлива для проникненню кальцію. Кальцій накопичується у клітині та пошкоджує іiі нормальне функціонування:збільшує кількість прозапальних цитокинів, що активують Купферовські клітини на виробку колагену II типу [3]. В результаті утворюється сполуно-тканинний тяж або септа. Створення ефективної моделі захворювання на тваринах, а саме на гризунах, дає можливість підвищити ефективність лікування уражень печінки у людей. 